Published in final edited form as:

Inorg Chem. 2017 November 06; 56(21): 13360-13367. doi:10.1021/acs.inorgchem.7b02114.

\title{
Tetranuclear Iron Clusters with A Varied Interstitial Ligand: Effects On Structure, Redox Properties, and Nitric Oxide Activation
}

\author{
Christopher J. Reed and Theodor Agapie* \\ Division of Chemistry and Chemical Engineering, California Institute of Technology, Pasadena, \\ California 91125, United States
}

\begin{abstract}
A new series of tetranuclear iron clusters displaying an interstitial $\mu_{4}-\mathrm{F}$ ligand was prepared for comparison to $\mu_{4} \mathrm{O}$ analogs. With a single $\mathrm{NO}$ coordinated as a reporter of small molecule activation, the $\mu_{4} \mathrm{~F}$ clusters were characterized in five redox states, from $\left.\mathrm{Fe}^{\mathrm{II}} 3 \mathrm{FeNO}\right\}^{8}$ to $\mathrm{Fe}^{\mathrm{III}}{ }_{3}\{\mathrm{FeNO}\}^{7}$, with $\mathrm{N}-\mathrm{O}$ stretching frequencies ranging from $1680 \mathrm{~cm}^{-1}$ to $1855 \mathrm{~cm}^{-1}$, respectively. Despite accessing more reduced states with an $\mathrm{F}^{-}$bridge, a two electron reduction of the distal $\mathrm{Fe}$ centers is necessary for the $\mu_{4} \mathrm{~F}$ clusters to activate NO to the same degree as the $\mu_{4}$ $\mathrm{O}$ system; consequently, $\mathrm{NO}$ reactivity is observed at more positive potentials with $\mu_{4} \mathrm{O}$ than $\mu_{4} \mathrm{~F}$. Moreover, the $\mu_{4} \mathrm{O}$ ligand better translates redox changes of remote metal centers to diatomic ligand activation. The implication for biological active sites is that the higher charge bridging ligand is more effective in tuning cluster properties, including the involvement of remote metal centers, for small molecule activation
\end{abstract}

\section{SYNOPSIS TOC}

A new series of tetranuclear iron clusters displaying a $\mu_{4} \mathrm{~F}$ ligand allows comparison to $\mu_{4} \mathrm{O}$ analogs to address the effect of the interstitial ligand. With a single NO coordinated as a reporter of small molecule activation capabilities, the $\mu_{4} \mathrm{~F}$ clusters were characterized in five redox states. The higher charge $\mu_{4} \mathrm{O}$ bridge results in more effective activation of NO through several effects.

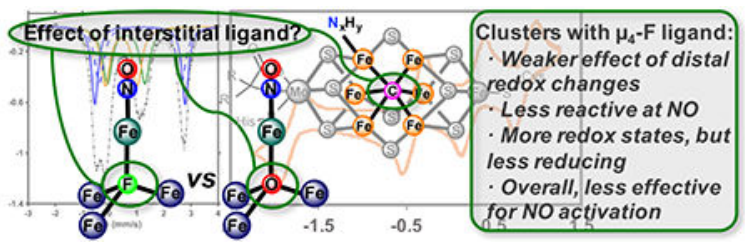

"Corresponding Author: agapie@caltech.edu.

Notes

The authors declare no competing financial interests.

\section{ASSOCIATED CONTENT}

Supporting Information

The Supporting Information is available free of charge on the ACS Publications website.

Crystallographic data files (CIFs)

Supplementary Data (PDF) 


\section{Introduction}

Transition metal clusters perform diverse functions in proteins, including metal storage, sensing, electron transfer, and multi-electron small molecule conversions (such as $\mathrm{H}_{2} \mathrm{O}$ oxidation, $\mathrm{CO}_{2}$ fixation, and $\mathrm{N}_{2}$ reduction). ${ }^{1} \mathrm{~A}$ common element of these multinuclear sites is the presence of highly bridged ( $2 \mu_{3}$ binding) single atom ligands, such as sulfide, ${ }^{2}$ oxide, ${ }^{3}$ or carbide. ${ }^{4}$ Quantitative measures of the effects these ligands play in small molecule activation remain rare. This is particularly relevant to understanding the role the interstitial $\mu_{\sigma}$ - Cligand in the FeMo cofactor (FeMoco) of nitrogenase (Figure 1A). Synthetic clusters suitable for structure-function studies of bridging ligands with respect to the activation of a small molecule are rare, likely because of design constraints hard to overcome by selfassembly, which is the route typically employed in cluster synthesis. Maintaining the exact same structure while changing the bridging ligands and redox states, while limiting ligand binding to a single small molecule, desirable for quantification of the effect and for mimicking substrate activation by protein active sites, are two major challenges. A host of iron-carbonyl clusters have been synthesized with a variety of bridging $\left(\geq \mu_{3}\right)$ single atom ligands, including $\mu_{6}$ - Clusters, such as $\left[\left(\mu_{6}-\mathrm{C}\right) \mathrm{Fe}_{6}(\mathrm{CO})_{16}\right]^{2-}$, with arrangements reminiscent of the FeMoco structure (Figure 1B, see SI for a comprehensive list). ${ }^{5}$ While a related cluster has been reported displaying a $\mu_{6} \mathrm{~N}$ ligand, $\left[\left(\mu_{6}-\mathrm{N}\right) \mathrm{Fe}_{6}(\mathrm{CO})_{15}\right]^{3-}$, with potential for structure function studies of the effect of the interstitial ligand, changes in the structure and number of $\mathrm{CO}$ ligands complicates interpretations. In the cases where completely isostructural clusters can be prepared with bridging elements of the second row of the periodic table, the large number $(\geq 9)$ of diatomic ligands limits interpretations regarding the activation of a single small molecule substrate, which is most relevant to biological systems. Recently, in an elegant demonstration of the effect of the $\mu_{4}$-ligand ( $\mathrm{N}$ vs C) on reactivity, the hydride ligands in $\left[\mathrm{HFe}_{4} \mathrm{C}(\mathrm{CO})_{12}\right]^{2-}$ and $\left[\mathrm{HFe}_{4} \mathrm{~N}(\mathrm{CO})_{12}\right]^{-}$have been shown to have distinct behavior for $\mathrm{H}_{2}$ and formate generation. ${ }^{6}$ Other synthetic clusters have been studied to address effects of a bridging ligand on redox potentials or to model FeMoco, but small molecule binding by the clusters with different bridging ligands has not been reported. ${ }^{7}$

Toward directly interrogating the effect of a cluster's interstitial ligand on reactivity, we have developed synthetic methodologies to access site differentiated multinuclear complexes that allow variation of the bridging ligands. Herein, we present investigations of a series of tetranuclear iron clusters containing a $\mu_{4} \mathrm{~F}$ motif, isostructural with our previously reported $\mu_{4} \mathrm{O}$ clusters (Figure 1A). ${ }^{8}$ These compounds allow for the evaluation of the effects of the nature of the interstitial atom on cluster properties related to the activation of a single diatomic ligand (NO).

\section{Results and Discussion}

We have recently reported the synthesis of site differentiated tetranuclear clusters, where three (basal) metal centers are co-ordinated by a hexapyridyl-trisalkoxide framework $\left(\mathbf{L}^{3-}\right.$, Figure 1) and bridged to a fourth (apical) metal site through three pyrazolate ligands and a $\mu_{4} \mathrm{O}$ ligand. ${ }^{8}$ The all ferrous fluoride-bridged cluster, $\mathbf{1}$, was synthesized via addition of a 2:1 ratio of phenylpyrazole and potassium phenylpyrazolate along with one equivalent 
anhydrous tetrabutylammonium fluoride to a previously reported trinuclear iron precursor $\left(\mathbf{L F e}_{3}(\mathbf{O A c})(\mathbf{O T f})_{2} \text {, Figure 1) }\right)^{8 \mathrm{a}, 9}$. The fourth Fe equivalent was delivered as $\mathrm{Fe}\left(\mathrm{N}\left(\mathrm{SiMe}_{3}\right)_{2}\right)_{2}$ to complete the tetranuclear cluster $(\mathbf{1})$. This redox neutral route of installing the interstitial $\mathrm{F}$ proved to be the most reliable way to avoid the generation of mixtures, with some $\mu_{4} \mathrm{O}$ clusters likely formed due to trace moisture. Subsequent chemical oxidations afford two additional redox states, $\mathrm{Fe}_{3}{ }_{3} \mathrm{Fe}^{\mathrm{III}}(\mathbf{2})$ and $\mathrm{Fe}^{\mathrm{II}}{ }_{2} \mathrm{Fe}^{\mathrm{III}}{ }_{2}(\mathbf{3})$.

Characterization by Mössbauer spectroscopy is consistent with charge localization on each $\mathrm{Fe}$ center and with oxidations occurring exclusively in the basal triiron core, the apical $\mathrm{Fe}$ remaining $\mathrm{Fe}^{\mathrm{II}}$ (Figures S26 - S31), as observed for the $\mu_{4} \mathrm{O}$ analogs. ${ }^{8 \mathrm{~b}}$ Structural characterization by single crystal X-ray diffraction (XRD) reveals that the most oxidized cluster, 3, displays a five coordinate apical Fe ${ }^{\mathrm{II}}$, due to acetonitrile binding (Figure S53). Removal of this ligand under vacuum results in decomposition. This behavior is in contrast to the analogous $\mu_{4} \mathrm{O}$ clusters, which have been isolated in the $\mathrm{Fe}^{\mathrm{II}}{ }_{2} \mathrm{Fe}^{\mathrm{III}}{ }_{2}$ and $\mathrm{Fe}^{\mathrm{II}} \mathrm{Fe}^{\mathrm{III}}{ }_{3}$ oxidation states, both displaying a four-coordinate apical $\mathrm{Fe}^{\mathrm{II}}$. This difference suggests that that the $\mu_{4} \mathrm{~F}$ clusters are more Lewis acidic than their $\mu_{4} \mathrm{O}$ analogues. Consistent with this interpretation, $\mu_{4} \mathrm{O}$ clusters with electron withdrawing substituents show increased coordination numbers at the apical metal. ${ }^{8 \mathrm{~b}}$

Nitric oxide provides a diagnostic vibrational spectroscopic signature for comparing different complexes to address the effects of the multinuclear supporting platform and the interstitial ligand on small molecule binding. ${ }^{10}$ Studies of the chemistry of iron clusters with nitric oxide has been principally focused on understanding the biologically relevant conversion of iron-sulfur clusters to nitrosylated products. ${ }^{11}$ However, there are few examples of multinuclear mononitrosyl complexes containing nearby redox-active metal centers. ${ }^{8 a}, 12$ The clusters targeted here provide insight into the influence of neighboring metal centers on the chemistry of the metal-nitrosyl moiety. Addition of NO to compound $\mathbf{1}$ leads to the formation of the corresponding nitrosyl adduct. Cyclic voltammetry of the monocationic nitrosyl cluster, 1-NO, displays three electrochemically quasi-reversible oxidations and one quasi-reversible reduction (Figure 2). Each of the five redox states of the nitrosyl clusters observed electrochemically was accessed synthetically (Figure 1). Stepwise treatment of 1-NO with AgOTf (2-NO and 3-NO) and [(2,4-Br- $\left.\left.\mathrm{C}_{6} \mathrm{H}_{4}\right)_{3} \mathrm{~N}\right]\left[\mathrm{SbCl}_{6}\right]$ (4-NO) provides access to the oxidized NO adducts. 4-NO decomposes in solution and as a solid on the time scale of attempted crystallizations, preventing structural characterization. Reduction of 1-NO with decamethylcobaltocene in acetonitrile precipitates a purple solid assigned as 5-NO. Dissolution of 5-NO in tetrahydrofuran, pyridine, or dichloromethane, leads to rapid decomposition preventing structural characterization of this complex as well. $\mathrm{N}_{2} \mathrm{O}$ is detected upon decomposition of 5-NO, albeit in low yield ( 0.1 equivalents, GC-MS).

Mössbauer spectroscopy was performed on 1-NO - 5-NO. As observed in the $\mu_{4} \mathrm{O}$ system, Mössbauer parameters are consistent with oxidations being localized at the basal triiron core as characterized previously. ${ }^{8 \mathrm{a}-\mathrm{c}, 13}$ In the Mössbauer spectrum of 1-NO, the Fe-NO signal is readily distinguished from the basal iron centers in the cluster, and was fit with an isomer shift $(\delta)$ of $0.62 \mathrm{~mm} / \mathrm{s}$ and a quadrupole splitting value $\left(\left|\Delta \mathrm{E}_{\mathrm{q}}\right|\right)$ of $1.16 \mathrm{~mm} / \mathrm{s}$ (Figure 3B; Table 1). The exact Mössbauer parameters for the Fe-NO centers in 2-NO - 4-NO are more difficult to assign due to spectral overlap with signals from the $\mathrm{Fe}^{\mathrm{III}}$ centers of the triiron 
core. The overlap is consistent, however, with only small changes in the Mössbauer parameters for the Fe-NO sites in 1-NO - 4-NO (Figures 3C-D and Table 1). These parameters are also similar to the previously reported $\mu_{4} \mathrm{O}$ NO clusters, which have $\delta$ values ranging from 0.55 to $0.62 \mathrm{~mm} / \mathrm{s}$, and $\left|\Delta \mathrm{E}_{\mathrm{q}}\right|$ values of 1.94 to $2.38 \mathrm{~mm} / \mathrm{s} .{ }^{8 \mathrm{a}}$ Overall, these data are consistent with the $\{\mathrm{FeNO}\}^{7}$ formulation, according to Enemark-Feltham notation. ${ }^{14}$ The Mössbauer spectrum of 5-NO was fit with three $\mathrm{Fe}^{\mathrm{II}}$ in the triiron core and an apical Fe-NO signal distinct from the ones observed for 1-NO - 4-NO, assigned as $\{\mathrm{FeNO}\}^{8}(\delta=$ $0.94 \mathrm{~mm} / \mathrm{s}$ and $\left|\Delta \mathrm{E}_{\mathrm{q}}\right|=1.63 \mathrm{~mm} / \mathrm{s}$; Figure 3A), consistent with reduction of the Fe-NO moiety rather than a remote metal site. Compounds 1-NO, 2-NO, and 3-NO were structurally characterized by XRD. In all cases, binding of $\mathrm{NO}$ to the apical Fe occurs in a linear fashion ( $\Psi \mathrm{e} 4-\mathrm{N} 40-\mathrm{O} 40>175^{\circ}$, Figure 4A). As observed in the $\mu_{4} \mathrm{O}$ system and from Mössbauer spectra (Figure 3B-D), bond metrics are consistent with oxidations being localized at the basal triiron core of these three clusters (Table 1). The $\mathrm{Fe}-\mu_{4} \mathrm{~F}$ bonds, which range from 2.07 to $2.24 \AA$, are longer than the $\mathrm{Fe}-\mu_{4} \mathrm{O}$ bonds ( 1.93 to $2.18 \AA$ ) despite the shorter ionic radius of $\mathrm{F}^{-}$which suggests a significantly weaker interaction with the fluoride resulting in more electron deficient metal centers. ${ }^{15}$ The Fe4-F distance increases $0.11 \AA$ Apon two oxidation events, similar to the geometry changes observed in the $\mu_{4} \mathrm{O}$ system $(0.12 \AA) .8 \mathrm{a}$

IR spectroscopy reveals a large range of $\nu_{\mathrm{N}-\mathrm{O}}$ for complexes 1-NO $-\mathbf{5 - N O}$, from $1680 \mathrm{~cm}$ -1 to $1855 \mathrm{~cm}^{-1}$ (Figure 4B and Figure S22). Comparison of $\nu_{\mathrm{N}-\mathrm{O}}$ for 1-NO - 4-NO (1799 $-1855 \mathrm{~cm}^{-1}$ ) provides insight into the effect of remote redox changes on NO activation. Oxidation of the Fe centers not bound to NO leads to an average of $19 \mathrm{~cm}^{-1}$ per redox change, with redox changes of more reduced clusters having a larger effect. The shift in $\nu_{\mathrm{N}-\mathrm{O}}$ to higher energy upon oxidation is matched by an increase in $\mathrm{Fe} 4-\mu_{4} \mathrm{~F}$ distance, and likely results from a more electron deficient $\mathrm{Fe} 4$ center due to this elongation. The nature and type of interaction with axial ligand has been previously demonstrated to effect the level of $\mathrm{NO}$ activation in mononuclear Fe complexes. ${ }^{16}$ Analogous shifts in the distance between $\mathrm{Fe}$ and axial ligands trans to coordinated $\mathrm{N}_{2}$ have been reported for monoiron models of nitrogenase. ${ }^{17}$

The correlation between the increase in the $\mathrm{Fe} 4-\mu_{4}$ ligand distance and the increase in the $\nu_{\mathrm{N}-\mathrm{O}}$ frequency observed previously for $\mu_{4} \mathrm{O}$ and now with $\mu_{4} \mathrm{~F}$ interstitial ligands suggests that this structural parameter generally serves to relay the effect of remote redox changes to the metal that binds the small molecule. However, the magnitude of change in NO activation as a result of these distal redox changes varies with the nature of the interstitial atom. For $\mu_{4}$ O clusters, the $\nu_{\mathrm{N}-\mathrm{O}}$ changes from $1715 / 1759$ to $1823 \mathrm{~cm}^{-1}$ over two redox events with an average change of $54 / 33 \mathrm{~cm}^{-1}$ per electron transfer, in contrast to only $19 \mathrm{~cm}^{-1}$ for $\mu_{4} \mathrm{~F}$. The stronger $\mathrm{O}^{2-}$ ligand roughly doubles the effect of remote redox changes on the activation of NO compared to $\mathrm{F}^{-}$. This is a unique observation, which relies on the ability to access many oxidiation states of these clusters, and demonstrates that an interstitial ligand can influence small molecule activation in two ways: first, by its direct interaction with the small-molecule binding metal center, and, second, by modulating the degree to which other metals in the cluster can perturb this metal-interstitial ligand interaction. Structural comparison of the $\mathrm{Fe} 4-\mu_{4}$-ligand distances over two oxidiation states shows that redox changes at the remote 
Fe centers shifts the $\mathrm{Fe} 4-\mu_{4} \mathrm{~F}$ distance by $0.09 \AA$ and the $\mathrm{Fe} 4-\mu_{4} \mathrm{O}$ bond by $0.12 \AA$ (Figure 4B). The more donating interstitial ligand is able to more efficiently translate remote redox changes in the cluster into NO activation.

A consequence of varying the $\mu_{4}$-ligand in these clusters is that the weaker $\mathrm{F}^{-}$donor increases the overall cluster charge of a particular redox state by one compared to the $\mathrm{O}^{2-}$ version. Separating the effect of higher positive charge from the effect of the donating abilities of the interstitial ligand on NO activation can be addressed by comparing clusters 2NO - 4-NO and the $\mu_{4} \mathrm{O}$ analogs. For the same cluster redox state, significantly higher $\nu_{\mathrm{N}-\mathrm{O}}$ are observed for the $\mu_{4} \mathrm{~F}$ ligand compared to $\mu_{4} \mathrm{O}$, as expected. The overall cluster charge, which is higher by one compared to $\mu_{4} \mathrm{O}$ clusters of the same Fe redox states, is not sufficient to explain the higher $\mathrm{NO}$ activation. Comparison of clusters of the same charge for $\mu_{4} \mathrm{O}$ and $\mu_{4} \mathrm{~F}$, but higher overall $\mathrm{Fe}$ redox state for $\mu_{4} \mathrm{O}$ (for example $\left(\mu_{4}\right.$ F) $\mathrm{Fe}^{\mathrm{II}} \mathrm{Fe}^{\mathrm{III}}{ }_{2}\{\mathrm{FeNO}\}^{7}($ 3-NO$)$ with $v_{\mathrm{N}-\mathrm{O}}=1842 \mathrm{~cm}^{-1}$ vs $\left(\mu_{4} \mathrm{O}\right) \mathrm{Fe}^{\mathrm{III}}{ }_{2}\{\mathrm{FeNO}\}^{7}$ with $\nu_{\mathrm{N}-\mathrm{O}}=$ $1823 \mathrm{~cm}^{-1}$ ), still shows higher degree of $\mathrm{NO}$ activation with $\mathrm{O}^{2-}$. This difference suggests that the higher charge interstitial ligand leads to a more electron rich cluster and a lower $v_{\mathrm{N}-\mathrm{O}}$ due to its direct interaction with the metal centers rather than solely due to the cluster charge.

IR spectroscopy of 5-NO corroborates the Mössbauer data and is consistent with the formation of a $\{\mathrm{FeNO}\}^{8}$ motif; the $\nu_{\mathrm{N}-\mathrm{O}}$ at $1680 \mathrm{~cm}^{-1}$, is $\sim 120 \mathrm{~cm}^{-1}$ lower than $\nu_{\mathrm{N}-\mathrm{O}}$ for the $\{\mathrm{FeNO}\}^{7}$ moiety of 1-NO. A similarly large shift was observed upon reduction for a structurally related mononuclear trigonal bipyramidal Fe-NO complex,${ }^{18}$ and more generally for non-heme $\left.\{\mathrm{FeNO}\}^{7 /\{\mathrm{FeNO}}\right\}^{8}$ complexes. ${ }^{19} \mathrm{An}$ analogous species is not observable for the $\mu_{4} \mathrm{O}$ clusters. Comparison of the redox potentials of the $\mu_{4} \mathrm{~F}$ and the $\mu_{4} \mathrm{O}$ system (Figure $4 \mathrm{~B})^{8 \mathrm{a}}$ reveals that the $\mathrm{F}^{-}$ligand shifts the redox potentials positively by approximately $1 \mathrm{~V}$ for the same cluster oxidation states compared to the $\mathrm{O}^{2-}$ ligand, due to the lower negative charge and electron donating ability of $\mathrm{F}^{-}$. An analogous effect is observed for other clusters upon changing the bridging ligand to alter the charge of the cluster. ${ }^{6,7 \mathrm{e}}$ The shift in redox potentials allows access to more reduced states of the $\mu_{4} \mathrm{~F}$ clusters within the electrochemical solvent window, which could be beneficial for storing additional reducing equivalents at more positive potentials. However, this is counterbalanced by weaker activation of the diatomic ligand, as reflected by IR spectroscopy (vide supra). In fact, to achieve the same level of NO activation, the $\mu_{4} \mathrm{~F}$ clusters need to have Fe oxidation states lower by two levels compared to the $\mu_{4} \mathrm{O}$ clusters. This is in contrast to the behavior observed for certain iron-multicarbonyl clusters, where data is available for isostructural motifs. For example, $\left[\mathrm{Fe}_{4} \mathrm{C}(\mathrm{CO})_{12}\right]^{2-}$ shows lower average $\mathrm{CO}$ activation than the one electron more reduced, but same-charge cluster, $\left[\mathrm{Fe}_{4} \mathrm{~N}(\mathrm{CO})_{12}\right]^{2-.6,20}$ The difference is likely a result of distribution of charge and small molecule activation over many (12) CO ligands. In the present system, which displays a more biomimetic, single ligand binding, redox changes at remote metal centers is relayed through the interstitial atom to a single Fe-NO moiety, providing a test for the ability of the $\mu_{4}$ ligand to communicate redox changes at metals not bound to the small molecule. Furthermore, differences in chemical reactivity of the diatomic ligand are observed. Addition of $\mathrm{NO}$ to $\left(\mu_{4} \mathrm{O}\right) \mathrm{Fe}^{\mathrm{II}}{ }_{2} \mathrm{Fe}^{\mathrm{III}}\{\mathrm{FeNO}\}^{7}$ leads to NO disproportionation to generate $\mathrm{N}_{2} \mathrm{O}$ and the one electron oxidized nitrosyl cluster. ${ }^{8 \mathrm{a}} \mathrm{In}$ 
contrast, addition of NO to 1-NO, which is one electron more reduced $\left(\left(\mu_{4} \mathrm{~F}\right) \mathrm{Fe}^{\mathrm{II}}{ }_{3}\{\mathrm{FeNO}\}^{7}\right)$ does not result in a reaction. This difference in reactivity as a function of interstitial ligand is likely due to a more activated $\mathrm{NO}$ and a $250 \mathrm{mV}$ lower redox potential for the $\mu_{4} \mathrm{O}$ cluster.

Only 5-NO, with an electronically different, $\{\mathrm{FeNO}\}^{8}$ moiety, undergoes conversion to $\mathrm{N}_{2} \mathrm{O}$ with a fluoride interstitial ligand, albeit not cleanly. Over-all, despite more negative potentials compared to $\mu_{4} \mathrm{~F}$ analogs of the same redox state, reactivity of $\mathrm{NO}$ is observed at milder potentials with the $\mu_{4} \mathrm{O}$ cluster.

\section{Summary}

In this report, we have demonstrated the significant effects that the change of interstitial ligands $\left(\mu_{4} \mathrm{O}\right.$ vs $\left.\mu_{4} \mathrm{~F}\right)$ has on the small molecule activation properties of tetranuclear iron clusters. The more positive redox potentials of $\mu_{4} \mathrm{~F}$ clusters allow access to more reduced $\mathrm{Fe}$ states. However, this does not result in more efficient activation of small molecule ligands, as inferred from IR spectroscopy and reactivity of $\mathrm{NO}$ complexes. The higher $\nu_{\mathrm{N}-\mathrm{O}}$ values of the $\mu_{4} \mathrm{~F}$ species for the same $\mathrm{Fe}$ oxidation states compared to the $\mu_{4} \mathrm{O}$ analogues are not due to the difference in cluster charge, but rather the nature of the interactions with the bridging ligand. To achieve similar NO activation, the cluster needs to be two electrons more reduced with the $\mu_{4} \mathrm{~F}$ compared to the $\mu_{4} \mathrm{O}$ ligand. Consequently, $\mathrm{NO}$ disproportionation is observed with a $\mu_{4} \mathrm{O}$ ligand at higher $\mathrm{Fe}$ oxidation states and more positive potentials than with a $\mu_{4} \mathrm{~F}$ ligand. Furthermore, the $\mu_{4} \mathrm{O}$ ligand is a better relay of remote redox changes. The structure-function studies described here suggest that a higher charge interstitial ligand, such as the carbide in FeMoco of nitrogenase, is more efficient at tuning cluster properties in a variety of ways toward the activation of small molecule. Analogs of the reported compounds with $\mu_{4} \mathrm{C}$ and $\mu_{4} \mathrm{~N}$ moieties would provide further quantitative measures of $\mathrm{NO}$ activation upon additional increase of the formal negative charge of the interstitial ligand; their syntheses are being pursued.

\section{Experimental Details}

\section{General Considerations}

All reactions were performed at room temperature in an $\mathrm{N}_{2}$-filled $\mathrm{M}$. Braun glovebox or using standard Schlenk techniques unless otherwise specified. Glassware was oven dried at $140{ }^{\circ} \mathrm{C}$ for at least $2 \mathrm{~h}$ prior to use, and allowed to cool under vacuum. $\mathbf{L F e}_{\mathbf{3}}(\mathbf{O A c})(\mathbf{O T f})_{2}{ }^{8 \mathrm{a}}$ $\mathrm{Fe}\left(\mathrm{N}\left(\mathrm{SiMe}_{3}\right)_{2}\right)_{2},{ }^{21}$ benzyl potassium, ${ }^{22} 1-H$-3-phenyl pyrazole $(\mathrm{HPhPz}),{ }^{23}$ anhydrous $\left[\mathrm{NBu}_{4}\right][\mathrm{F}]^{24}$, and $\left[\left(2,4-\mathrm{Br}_{-} \mathrm{C}_{6} \mathrm{H}_{3}\right)_{3} \mathrm{~N}\right]\left[\mathrm{SbCl}_{6}\right]^{25}$ were prepared according to literature procedures. [(4-Br- $\left.\left.\mathrm{C}_{6} \mathrm{H}_{4}\right)_{3} \mathrm{~N}\right][\mathrm{OTf}]$ was prepared according to a modified literature procedure. ${ }^{26}$ Tetrahydrofuran was dried using sodium/benzophenone ketyl, degassed with three freeze-pump-thaw cycles, vacuum transferred, and stored over $3 \AA$ molecular sieves prior to use. $\mathrm{CH}_{2} \mathrm{Cl}_{2}$, diethyl ether, benzene, acetonitrile, hexanes, and pentane were dried by sparging with nitrogen for at least 15 minutes, then passing through a column of activated A2 alumina under positive $\mathrm{N}_{2}$ pressure. ${ }^{1} \mathrm{H}$ and ${ }^{19} \mathrm{~F}$ NMR spectra were recorded on a Varian $300 \mathrm{MHz}$ spectrometer. ${ }^{13} \mathrm{C}$ NMR spectra were recorded on a Varian $500 \mathrm{MHz}$ spectrometer. $\mathrm{CD}_{3} \mathrm{CN}$ and $\mathrm{CD}_{2} \mathrm{Cl}_{2}$ was purchased from Cambridge Isotope Laboratories, dried over calcium hydride, degassed by three freeze-pump-thaw cycles, and vacuum transferred prior 
to use. Infrared (ATR-IR) spectra were recorded on a Bruker ALPHA ATR-IR spectrometer at $4 \mathrm{~cm}^{-1}$ resolution. Headspace analysis was conducted on a HP 5972 GC-MS.

\section{Physical Methods}

Mössbauer measurements-Zero applied field ${ }^{57} \mathrm{Fe}$ Mossbauer spectra were recorded at $80 \mathrm{~K}$ in constant acceleration mode on a spectrometer from See Co (Edina, MN) equipped with an SVT-400 cryostat (Janis, Wilmington, WA). The isomer shifts are relative to the centroid of an a-Fe foil signal at room temperature. Samples were prepared by mixing polycrystalline material $(20 \mathrm{mg}$ ) with boron nitride in a cup fitted with screw cap or freezing a concentrated acetonitrile solution in the cup. The data were fit to Lorentzian lineshapes using WMOSS (www.wmoss.org).

Electrochemical measurements-CVs and SWVs were recorded with a Pine Instrument Company AFCBP1 biopotentiostat with the AfterMath software package. All measurements were performed in a three electrode cell, which consisted of glassy carbon (working; $\varnothing=3.0 \mathrm{~mm}$ ), silver wire (counter) and bare platinum wire (reference), in a $\mathrm{N}_{2}$ filled M. Braun glovebox at RT. Dry acetonitrile or $\mathrm{CH}_{2} \mathrm{Cl}_{2}$ that contained $\sim 85 \mathrm{mM}\left[\mathrm{Bu}_{4} \mathrm{~N}\right]$ $\left[\mathrm{PF}_{6}\right]$ was used as the electrolyte solution. The ferrocene/ferrocinium $\left(\mathrm{Fc} / \mathrm{Fc}^{+}\right)$redox wave was used as an internal standard for all measurements.

X-ray crystallography-X-ray diffraction data was collected at $100 \mathrm{~K}$ on a Bruker PHOTON100 CMOS based diffractometer (microfocus sealed X-ray tube, Mo Ka $(\lambda)=$ $0.71073 \AA$ or $\mathrm{Cu} \mathrm{Ka}(\lambda)=1.54178 \AA$ ). All manipulations, including data collection, integration, and scaling, were carried out using the Bruker APEXII software. Absorption corrections were applied using SADABS. Structures were solved by direct methods using XS (incorporated into SHELXTL) and refined by using ShelXL least squares on Olex2-1.2.7 to convergence. All non-hydrogen atoms were refined using anisotropic displacement parameters. Hydrogen atoms were placed in idealized positions and were refined using a riding model. Due to the size of the compounds (1 - 3 and 1-NO - 3-NO), most crystals included solvent-accessible voids that contained disordered solvent. In most cases the solvent could be modeled satisfactorily.

\section{Synthetic Procedures}

Synthesis of Potassium 3-phenyl-pyrazolate (KPhPz)-In the glovebox, a solution of 1- $H$-3-phenyl-pyrazole $(1.54 \mathrm{~g}, 11.8 \mathrm{mmol})$ in THF $(5 \mathrm{~mL})$ was stirred while a solution of benzyl potassium $(1.70 \mathrm{~g}, 11.8 \mathrm{mmol})$ in THF $(10 \mathrm{~mL})$ was added drop-wise. Addition caused the solution to change from colorless to pale yellow. After 30 minutes, the solvent was removed under reduced pressure to obtain $1.83 \mathrm{~g}$ off-white powder $\left(85 \%\right.$ yield). ${ }^{1} \mathrm{H}$ NMR (300 MHz, CD $\left.{ }_{3} \mathrm{CN}\right) \delta 7.83(\mathrm{~d}, 2 \mathrm{H}), 7.44(\mathrm{~s}, 1 \mathrm{H}), 7.28(\mathrm{t}, 2 \mathrm{H}), 7.07(\mathrm{t}, 1 \mathrm{H}), 6.39(\mathrm{~s}$, $1 \mathrm{H}) .{ }^{13} \mathrm{C} \mathrm{NMR}\left(500 \mathrm{MHz}, \mathrm{CD}_{3} \mathrm{CN}\right) \delta 100.01(\mathrm{Pz} \mathrm{NCCH}), 125.02(p-\mathrm{Ar} C \mathrm{H}), 125.37(\mathrm{~m}-\mathrm{Ar}$ $C \mathrm{H}), 128.98(o-\mathrm{Ar} C \mathrm{H}), 139.34$ (Pz $C \mathrm{HCHN}), 150.27$ (Pz NCCH). An expected signal $138 \mathrm{ppm}(i \text {-Ar } C)^{8 \mathrm{a}}$ could not be observed, likely due to the low solubility of KPhPz.

Synthesis of tris-4-bromo-phenylamininum trifluoromethanesulfonate ([(4- $\mathrm{Br}-$ $\left.\left.\mathrm{C}_{6} \mathrm{H}_{4}\right)_{3} \mathrm{~N}\right][\mathrm{OTf}]$ )—This was prepared through a modification of a literature procedure for 
$\left[\left(4-\mathrm{Br}_{-} \mathrm{C}_{6} \mathrm{H}_{4}\right)_{3} \mathrm{~N}\right]\left[\mathrm{BF}_{4}\right]{ }^{26}$ Tris-4-bromo-phenylamine (1.5 g, $\left.3.11 \mathrm{mmol}\right)$ was dissolved in 30 $\mathrm{mL}$ diethyl ether with silver trifluoromethanesulfonate (AgOTf; $1.2 \mathrm{~g}, 4.67 \mathrm{mmol}$ ). This light green solution was added to a $100 \mathrm{~mL}$ Schlenk tube and cooled to $-40{ }^{\circ} \mathrm{C}$ under $\mathrm{N}_{2}$ atmosphere. Iodine powder $(0.75 \mathrm{~g}, 2.96 \mathrm{mmol})$ was added with a counter-flow of $\mathrm{N}_{2}$ while stirring; addition caused the solution to turn dark blue. The Schlenk tube was warmed to room temperature and filtered over a course porosity frit. The collected precipitate was filtered with $30 \mathrm{~mL} \mathrm{CH}_{2} \mathrm{Cl}_{2}$ in the glovebox. To the resulting dark blue solution, $40 \mathrm{~mL}$ diethyl ether was added and the flask was cooled to $-40{ }^{\circ} \mathrm{C}$. [(4-Br- $\left.\left.\mathrm{C}_{6} \mathrm{H}_{4}\right)_{3} \mathrm{~N}\right][\mathrm{OTf}]$ was collected as a dark purple solid upon filtration (1.36 g, 69\% yield). Anal. Calc. (\%) for $\mathrm{C}_{19} \mathrm{H}_{12} \mathrm{Br}_{3} \mathrm{~F}_{3} \mathrm{NO}_{3} \mathrm{~S}: \mathrm{C}, 36.16 ; \mathrm{H}, 1.92 ; \mathrm{N}, 2.22$. Found: C, 36.70; H, 1.94; N, 2.27.

Synthesis of [ $\left.\mathrm{LFe}_{3} \mathrm{~F}(\mathrm{PhPz})_{3} \mathrm{Fe}\right][\mathrm{OTf}]$ (1)-In the glovebox, a suspension of $\mathrm{LFe}_{3}(\mathrm{OAc})$ (OTf) 2 (1047 mg, $0.76 \mathrm{mmol})$ in THF (3 mL) was frozen in the cold well. To the thawing suspension, solutions of potassium 3-phenyl-pyrazolate (190 mg, $1.04 \mathrm{mmol}$ ) in THF (3 mL) and 1- $H$-3-phenyl-pyrzole $(220 \mathrm{mg}, 1.52 \mathrm{mmol})$ in THF (3 mL) were added. The suspension changed color from yellow to orange upon addition of the potassium 3-phenyl-pyrazolate. $\left[\mathrm{Bu}_{4} \mathrm{~N}\right][\mathrm{F}](208 \mathrm{mg}, 0.79 \mathrm{mmol})$ was added as a suspension in THF $(3 \mathrm{~mL})$, causing the solution to become dark red. A solution of $\mathrm{Fe}\left(\mathrm{N}\left(\mathrm{SiMe}_{3}\right)_{2}\right)_{2}(288 \mathrm{mg}, 0.76 \mathrm{mmol})$ in THF (2 $\mathrm{mL}$ ) was added. The reaction was stirred for $20 \mathrm{~h}$, after which an orange precipitate was observed. The suspension was filtered over a bed of celite on a fine porosity glass frit and washed with $5 \mathrm{~mL}$ THF. The orange solid was collected with $60 \mathrm{~mL}$ acetonitrile. The solvent was removed under reduced pressure to obtain $\left[\mathrm{LFe}_{3} \mathrm{~F}(\mathrm{PhPz})_{3} \mathrm{Fe}\right][\mathrm{OTf}]$ as an orange solid (950 mg, 75\% yield). ${ }^{1} \mathrm{H}$ NMR (300 MHz, $\mathrm{CD}_{2} \mathrm{Cl}_{2}$ ) $\delta 104.77,78.57,75.13,48.82,37.46$, $30.48,27.17,26.44,25.63,19.69,18.42,11.60,10.53,4.54,4.22,3.44,1.99,1.27,1.16$, $-1.13,-2.80,-46.96 .{ }^{19} \mathrm{~F}$ NMR $\left(300 \mathrm{MHz}, \mathrm{CD}_{2} \mathrm{Cl}_{2}\right) \delta-78.45$. UV-vis $\left(\mathrm{CH}_{2} \mathrm{Cl}_{2}\right)\left[\varepsilon\left(\mathrm{M}^{-1}\right.\right.$ $\left.\mathrm{cm}^{-1}\right)$ ]: $251 \mathrm{~nm}\left(9.2 \times 10^{4}\right), 463 \mathrm{~nm}\left(3.9 \times 10^{3}\right)$. Anal. Calcd. (\%) for $\mathrm{C}_{85} \mathrm{H}_{60} \mathrm{~F}_{4} \mathrm{Fe}_{4} \mathrm{~N}_{12} \mathrm{O}_{6} \mathrm{~S}$ : C, 60.88; H, 3.61; N, 10.02. Found: C, 61.16; H, 3.75; N, 9.74.

Synthesis of [LFe $\left.{ }_{3} \mathrm{~F}(\mathrm{PhPz})_{3} \mathrm{Fe}\right][\mathrm{OTf}]_{2}$ (2)-To a suspension of $\left[\mathrm{LFe}_{3} \mathrm{~F}(\mathrm{PhPz})_{3} \mathrm{Fe}\right][\mathrm{OTf}]$ (1; $94 \mathrm{mg}, 0.06 \mathrm{mmol})$ in THF (2 mL), a solution of AgOTf (14 mg, $0.06 \mathrm{mmol})$ in THF (2 $\mathrm{mL}$ ) was added. The color of the suspension changed from orange to brown and, after 2 hours, the solvent was removed under reduced pressure. The brown residue was dissolved in $\mathrm{CH}_{2} \mathrm{Cl}_{2}$ and filtered over a bed of celite on glass filter paper. The solvent was removed under reduced pressure to obtain $\left[\mathrm{LFe}_{3} \mathrm{~F}(\mathrm{PhPz})_{3} \mathrm{Fe}\right][\mathrm{OTf}]_{2}$ as a brown solid $(100 \mathrm{mg}, 98 \%$ yield $)$. ${ }^{1} \mathrm{H}$ NMR $\left(300 \mathrm{MHz}, \mathrm{CD}_{2} \mathrm{Cl}_{2}\right) \delta 101.33,87.83,79.33,47.73,46.79,35.24,34.14,28.86$, $26.35,18.15,16.58,16.33,12.10,8.55,7.28,6.79,6.25,5.25,4.63,-42.36 .{ }^{19} \mathrm{~F}$ NMR (300 $\left.\mathrm{MHz}, \mathrm{CD}_{2} \mathrm{Cl}_{2}\right)-78.19$. UV-vis $\left(\mathrm{CH}_{2} \mathrm{Cl}_{2}\right)\left[\varepsilon\left(\mathrm{M}^{-1} \mathrm{~cm}^{-1}\right)\right]: 250 \mathrm{~nm}\left(10.9 \times 10^{4}\right), 432 \mathrm{~nm}(4.8$ $\times 10^{3}$ ). Anal. Calcd. (\%) for $\mathrm{C}_{86} \mathrm{H}_{60} \mathrm{~F}_{7} \mathrm{Fe}_{4} \mathrm{~N}_{12} \mathrm{O}_{9} \mathrm{~S}_{2}$ : C, 56.57; H, 3.31; N, 9.21. Found: $\mathrm{C}$, $56.47 ; \mathrm{H}, 3.13 ; \mathrm{N}, 8.88$.

Synthesis of $\left[\mathrm{LFe}{ }_{3} \mathrm{~F}(\mathrm{PhPz})_{3} \mathrm{Fe}\left(\mathrm{CH}_{3} \mathrm{CN}\right)\right][\mathrm{OTf}]_{3}$ (3)-To a stirring solution of $\left[\mathrm{LFe}{ }_{3} \mathrm{~F}(\mathrm{PhPz})_{3} \mathrm{Fe}\right][\mathrm{OTf}]_{2}(2 ; 78.5 \mathrm{mg}, 0.04 \mathrm{mmol})$ in acetonitrile $(2 \mathrm{~mL}),\left[\left(\mathrm{p}-\mathrm{Br}-\mathrm{C}_{6} \mathrm{H}_{4}\right)_{3} \mathrm{~N}\right]$ [OTf] $(27.1 \mathrm{mg}, 0.04 \mathrm{mmol})$ was added as an acetonitrile solution $(2 \mathrm{~mL})$. The brown solution became purple upon addition. After 30 minutes, the solution was filtered. $5 \mathrm{~mL}$ of $\mathrm{CH}_{2} \mathrm{Cl}_{2}$ was added to the filtrate, then $10 \mathrm{~mL}$ pentane, to obtain a purple precipitate. The 
supernatant was decanted and the remaining solid was briefly dried under reduced pressure to obtain $\left[\mathrm{LFe}_{3} \mathrm{~F}(\mathrm{PhPz})_{3} \mathrm{Fe}\left(\mathrm{CH}_{3} \mathrm{CN}\right)\right][\mathrm{OTf}]_{3}$ as a purple solid $\left(42.3 \mathrm{mg}, 50 \%\right.$ yield). ${ }^{1} \mathrm{H}$ NMR $\left(300 \mathrm{MHz}, \mathrm{CD}_{3} \mathrm{CN}\right) \delta 125.15,91.53,82.45,80.10,61.48,51.98,43.99,15.30,13.93$, 12.33, 8.44, 6.48, 5.67, 5.30, 0.46, -5.74, $-18.78 .{ }^{19} \mathrm{~F} \mathrm{NMR}\left(300 \mathrm{MHz}, \mathrm{CD}_{3} \mathrm{CN}\right)-75.66$. UV-vis $\left(\mathrm{CH}_{2} \mathrm{Cl}_{2}\right)\left[\varepsilon\left(\mathrm{M}^{-1} \mathrm{~cm}^{-1}\right)\right]$ : $250 \mathrm{~nm}\left(10.3 \times 10^{4}\right), 465 \mathrm{~nm}\left(3.6 \times 10^{3}\right)$. Anal. Calcd. $(\%)$ for $\mathrm{C}_{88} \mathrm{H}_{62} \mathrm{Cl}_{2} \mathrm{~F}_{10} \mathrm{Fe}_{4} \mathrm{~N}_{12} \mathrm{O}_{12} \mathrm{~S}_{3}\left(3\right.$ with $\mathrm{CH}_{2} \mathrm{Cl}_{2}$ instead of $\mathrm{CH}_{3} \mathrm{CN}$; compound recrystallized in $\mathrm{CH}_{2} \mathrm{Cl}_{2}$ ): $\mathrm{C}, 51.31 ; \mathrm{H}, 3.03 ; \mathrm{N}, 8.16$. Found: $\mathrm{C}, 51.26 ; \mathrm{H}, 3.04 ; \mathrm{N}, 8.43$.

\section{Synthesis of $\left[\mathrm{LFe}_{3} \mathrm{~F}(\mathrm{PhPz})_{3} \mathrm{Fe}(\mathrm{NO})\right][\mathrm{OTf}](1-\mathrm{NO})$}

Method A: In the glovebox, a $100 \mathrm{~mL}$ Schlenk tube was charged with a solution of $\left[\mathrm{LFe}_{3} \mathrm{~F}(\mathrm{PhPz})_{3} \mathrm{Fe}\right][\mathrm{OTf}](\mathbf{1} ; 179 \mathrm{mg}, 0.11 \mathrm{mmol})$ in $\mathrm{CH}_{2} \mathrm{Cl}_{2}(5 \mathrm{~mL})$. The solution was degassed by three freeze-pump-thaw cycles. While frozen, gaseous nitric oxide $(33 \mathrm{~mL}, 59$ $\mathrm{mmHg}, 0.11 \mathrm{mmol}$ ) was condensed in the tube. The reaction was stirred at room temperature for $2 \mathrm{~h}$ and changed color from orange to brown. The solvent was removed under reduced pressure to yield $\left[\mathrm{LFe}_{3} \mathrm{~F}(\mathrm{PhPz})_{3} \mathrm{Fe}(\mathrm{NO})\right][\mathrm{OTf}]$ as a brown solid (181 mg, 99\% yield). ${ }^{1} \mathrm{H}$ NMR (300 MHz, $\left.\mathrm{CD}_{2} \mathrm{Cl}_{2}\right) \delta 98.43,76.64,74.24,42.59,40.12,35.92,32.51,27.06,20.05$, 15.27, 14.16, 11.24, 10.79, 4.27, 2.46, 1.13, 0.58, 0.46, -10.77, $-23.61 .{ }^{19} \mathrm{~F}$ NMR (300 $\mathrm{MHz}, \mathrm{CD}_{2} \mathrm{Cl}_{2}$ ) $\delta$-78.71. Anal. Calcd. (\%) for $\mathrm{C}_{86} \mathrm{H}_{62} \mathrm{Cl}_{2} \mathrm{~F}_{4} \mathrm{Fe}_{4} \mathrm{~N}_{13} \mathrm{O}_{7} \mathrm{~S}\left(\mathbf{1}-\mathrm{NO} \cdot \mathrm{CH}_{2} \mathrm{Cl}_{2}\right.$; compound recrystallized from $\mathrm{CH}_{2} \mathrm{Cl}_{2}$ /pentane): $\mathrm{C}, 57.66 ; \mathrm{H}, 3.49 ; \mathrm{N}, 10.16$. Found: $\mathrm{C}$, 57.40; H, 3.46; N, 10.01 .

Method B: In the glovebox, solid $\mathrm{LFe}_{3} \mathrm{~F}(\mathrm{PhPz})_{3} \mathrm{Fe}(\mathrm{NO})$ (5-NO; $22 \mathrm{mg}, 0.014 \mathrm{mmol}$ ) was cooled to $-196{ }^{\circ} \mathrm{C}$ in a cold well in a $20 \mathrm{~mL}$ vial with a stir bar. AgOTf $(3.7 \mathrm{mg}, 0.014$ $\mathrm{mmol}$ ) in $0.5 \mathrm{~mL}$ thawing tetrahydrofuran was added to the cooled powder. This reaction was stirred at room temperature for 30 minutes then pumped down. The purple suspension became a brown solution. ${ }^{1} \mathrm{H}$ NMR analysis of the crude reaction showed mostly (>90\%) $\left[\mathrm{LFe}_{3} \mathrm{~F}(\mathrm{PhPz})_{3} \mathrm{Fe}(\mathrm{NO})\right][\mathrm{OTf}]$ (1-NO; Figure S22). The brown solid was filtered in $\mathrm{CH}_{2} \mathrm{Cl}_{2}$ to obtain $16.8 \mathrm{mg}$ of $\left[\mathrm{LFe}_{3} \mathrm{~F}(\mathrm{PhPz})_{3} \mathrm{Fe}(\mathrm{NO})\right][\mathrm{OTf}]$ after recrystallization (69\% yield).

\section{Synthesis of $\left[\mathrm{LFe}_{3} \mathrm{~F}(\mathrm{PhPz})_{3} \mathrm{Fe}(\mathrm{NO})\right][\mathrm{OTf}]_{2}$ (2-NO)}

Method A: In the glovebox, a $100 \mathrm{~mL}$ Schlenk tube was charged with a solution of $\left[\mathrm{LFe}_{3} \mathrm{~F}(\mathrm{PhPz})_{3} \mathrm{Fe}\right][\mathrm{OTf}]_{2}(2 ; 163 \mathrm{mg}, 0.09 \mathrm{mmol})$ in $\mathrm{CH}_{2} \mathrm{Cl}_{2}(5 \mathrm{~mL})$. The solution was degassed by three freeze-pump-thaw cycles. While frozen, gaseous nitric oxide $(33 \mathrm{~mL}, 50$ $\mathrm{mmHg}, 0.09 \mathrm{mmol}$ ) was condensed in the tube. The reaction was stirred at room temperature for $2 \mathrm{~h}$, changing color from brown to yellow-green. The solvent was removed under reduced pressure to yield $\left[\mathrm{LFe}_{3} \mathrm{~F}(\mathrm{PhPz})_{3} \mathrm{Fe}(\mathrm{NO})\right][\mathrm{OTf}]_{2}$ as a dark green solid $(162 \mathrm{mg}, 98 \%$ yield). ${ }^{1} \mathrm{H}$ NMR (300 MHz, $\left.\mathrm{CD}_{2} \mathrm{Cl}_{2}\right) \delta 100.10,83.22,80.63,66.68,50.74,46.79,41.32$, $17.25,14.62,14.38,12.35,11.71,3.31,0.30,-3.31,-17.33 .{ }^{19} \mathrm{~F}\left(300 \mathrm{MHz}, \mathrm{CD}_{2} \mathrm{Cl}_{2}\right) \delta$ -77.52. Anal. Calcd. (\%) for $\mathrm{C}_{86} \mathrm{H}_{60} \mathrm{~F}_{7} \mathrm{Fe}_{4} \mathrm{~N}_{13} \mathrm{O}_{10} \mathrm{~S}_{2}$ : C, 55.65; H, 3.26; N, 9.81. Found: C, $55.59 ; \mathrm{H}, 3.25 ; \mathrm{N}, 9.53$.

Method B: In the glovebox, a solution of [ $\left.\mathrm{LFe}_{3} \mathrm{~F}(\mathrm{PhPz})_{3} \mathrm{Fe}(\mathrm{NO})\right][\mathrm{OTf}](\mathbf{1}-\mathrm{NO} ; 160 \mathrm{mg}$, $0.10 \mathrm{mmol})$ in acetonitrile $(3 \mathrm{~mL})$ was added to a solution of AgOTf $(25 \mathrm{mg}, 0.10 \mathrm{mmol})$ in acetonitrile $(2 \mathrm{~mL})$. The solution changed color from brown to yellow-green. After $1 \mathrm{~h}$, the solvent was removed under reduced pressure. The green residue was dissolved in $\mathrm{CH}_{2} \mathrm{Cl}_{2}$ 
and filtered over a bed of celite. The solvent was removed under reduced pressure to obtain $\left[\mathrm{LFe}_{3} \mathrm{~F}(\mathrm{PhPz})_{3} \mathrm{Fe}(\mathrm{NO})\right][\mathrm{OTf}]_{2}$ as a dark green solid (164 mg, 95\% yield). ${ }^{1} \mathrm{H}$ NMR is identical to that observed for method $\mathrm{A}$.

Synthesis of $\left[\mathrm{LFe}_{3} \mathrm{~F}(\mathrm{PhPz})_{3} \mathrm{Fe}(\mathrm{NO})\right][\mathrm{OTf}]_{3}$ (3-NO) - In the glovebox, a solution of $\left[\mathrm{LFe}{ }_{3} \mathrm{~F}(\mathrm{PhPz})_{3} \mathrm{Fe}(\mathrm{NO})\right][\mathrm{OTf}]_{2}$ (2-NO; $\left.27.6 \mathrm{mg}, 0.015 \mathrm{mmol}\right)$ in $\mathrm{CH}_{2} \mathrm{Cl}_{2}(1 \mathrm{~mL})$ was stirred as a solution of [(4-Br- $\left.\left.\mathrm{C}_{6} \mathrm{H}_{4}\right)_{3} \mathrm{~N}\right][\mathrm{OTf}](10.0 \mathrm{mg}, 0.016 \mathrm{mmol})$ in $\mathrm{CH}_{2} \mathrm{Cl}_{2}(1 \mathrm{~mL})$ was added. The addition caused the yellow-green solution to turn purple. After 30 minutes, the reaction was filtered and layered under pentane to afford purple crystals of $\left[\mathrm{LFe}_{3} \mathrm{~F}(\mathrm{PhPz})_{3} \mathrm{Fe}(\mathrm{NO})\right]$ $[\mathrm{OTf}]_{3}\left(20.3 \mathrm{mg}, 68 \%\right.$ yield). ${ }^{1} \mathrm{H}$ NMR $\left(300 \mathrm{MHz}, \mathrm{CD}_{2} \mathrm{Cl}_{2}\right) \delta$ 123.58, 98.80, 89.32, 60.89, 41.42, 14.25, 13.41, 10.34, 5.32, 4.35, 3.93, 3.71, 3.47, 2.07, 1.85, 1.18, -2.45, -8.26. Anal. Calcd. (\%) for $\mathrm{C}_{87} \mathrm{H}_{60} \mathrm{~F}_{10} \mathrm{Fe}_{4} \mathrm{~N}_{13} \mathrm{O}_{13} \mathrm{~S}_{3}: \mathrm{C}, 52.12 ; \mathrm{H}, 3.02 ; \mathrm{N}, 9.08$. Found: C, 51.88; H, $2.94 ; \mathrm{N}, 8.74$.

Synthesis of $\left[\mathrm{LFe}_{3} \mathrm{~F}(\mathrm{PhPz})_{3} \mathrm{Fe}(\mathrm{NO})\right][\mathrm{OTf}]_{3}\left[\mathrm{SbCl}_{6}\right]$ (4-NO)-In the glovebox, a thawing solution of $\left[\mathrm{LFe}_{3} \mathrm{~F}(\mathrm{PhPz})_{3} \mathrm{Fe}(\mathrm{NO})\right][\mathrm{OTf}]_{3}(3-\mathrm{NO} ; 25.7 \mathrm{mg}, 0.013 \mathrm{mmol})$ in $\mathrm{CH}_{2} \mathrm{Cl}_{2}$ $(1 \mathrm{~mL})$ was stirred as a solution of $\left[\left(2,4-\mathrm{Br}^{-} \mathrm{C}_{6} \mathrm{H}_{3}\right)_{3} \mathrm{~N}\right]\left[\mathrm{SbCl}_{6}\right](13.9 \mathrm{mg}, 0.013 \mathrm{mmol})$ in $\mathrm{CH}_{3} \mathrm{CN}(1 \mathrm{~mL})$ was added. The addition caused the purple solution to turn blue. Cold toluene was added until a precipitate was observed. This was kept in a liquid nitrogen-cooled cold well for 2 minutes. The supernatant was decanted and the resulting solid was dried under vacuum. This afforded $\left[\mathrm{LFe}_{3} \mathrm{~F}(\mathrm{PhPz})_{3} \mathrm{Fe}(\mathrm{NO})\right][\mathrm{OTf}]_{3}\left[\mathrm{SbCl}_{6}\right]$ as a blue solid $(15 \mathrm{mg}$, $49 \%$ yield). This compound decomposes over time in solution and the solid state, even at reduced temperatures. Characterization of this compound was conducted with freshly prepared samples to minimize decomposition. ${ }^{1} \mathrm{H}$ NMR $\left(300 \mathrm{MHz}, \mathrm{CD}_{3} \mathrm{CN}\right) \delta 124.54$, 97.65, 80.33, 77.50, 74.55, 37.57, 18.30, 15.25, 13.39, 9.04, 0.01, -1.66, -5.71, -6.88. Anal. Calcd. (\%) for $\mathrm{C}_{101} \mathrm{H}_{76} \mathrm{Cl}_{6} \mathrm{~F}_{10} \mathrm{Fe}_{4} \mathrm{~N}_{13} \mathrm{O}_{13} \mathrm{~S}_{3} \mathrm{Sb}$ ( $\mathrm{NO}_{4} \cdot 2 \mathrm{C}_{7} \mathrm{H}_{8}$; compound precipitated with toluene): C, 48.07; H, 3.04; N, 7.21. Found: C, 47.83; H, 2.97; N, 7.88.

Synthesis of $\mathrm{LFe}_{3} \mathrm{~F}(\mathrm{PhPz})_{3} \mathrm{Fe}(\mathrm{NO})$ (5-NO)—In the glovebox, a solution of $\left[\mathrm{LFe}{ }_{3} \mathrm{~F}(\mathrm{PhPz})_{3} \mathrm{Fe}(\mathrm{NO})\right][\mathrm{OTf}](\mathbf{1 - N O} ; 82.9 \mathrm{mg}, 0.049 \mathrm{mmol})$ in $\mathrm{CH}_{3} \mathrm{CN}$ was stirred as a solution of $\mathrm{CoCp}_{2}{ }_{2}(16.8 \mathrm{mg}, 0.051 \mathrm{mmol})$ in $\mathrm{CH}_{3} \mathrm{CN}$ was added. The addition caused the brown solution to become a purple suspension. After 2 hours, the solids were collected, washed with minimal $\mathrm{CH}_{3} \mathrm{CN}$, and dried under vacuum to afford $\mathrm{LFe}_{3} \mathrm{~F}(\mathrm{PhPz})_{3} \mathrm{Fe}(\mathrm{NO})$ as a purple solid (44.3 mg, 59\% yield). This species decomposes upon dissolution in tetrahydrofuran, pyridine, or $\mathrm{CH}_{2} \mathrm{Cl}_{2}$ and is mostly insoluble in acetonitrile, benzene, and toluene. Therefore, NMR and UV-Vis Absorbance data could not be collected for this complex. Anal. Calcd. (\%) for $\mathrm{C}_{84} \mathrm{H}_{60} \mathrm{FFe}_{4} \mathrm{~N}_{13} \mathrm{O}_{4}$ : C, 64.76; H, 3.88; N, 11.69. Found: C, 64.21; H, 3.86; N, 11.51 .

Addition of 6 equiv. NO to nitrosyl clusters 1-NO - 3-NO-In the glovebox, 0.01 mmol of a nitrosyl cluster 1-NO - 3-NO was dissolved in $0.5 \mathrm{~mL} \mathrm{CD}_{3} \mathrm{CN}$ and added to a J. Young tube. On the Schlenk line, the solution was degassed by three freeze-pump-thaw cycles. While frozen, $0.06 \mathrm{mmol}$ of gaseous NO was condensed in the tube. The tube was sealed and thawed. 
Decomposition of $\mathrm{LFe}_{3} \mathrm{~F}(\mathrm{PhPz})_{3} \mathrm{Fe}(\mathrm{NO})$ (5-NO) - In the glovebox, solid $\mathrm{LFe}_{3} \mathrm{~F}(\mathrm{PhPz})_{3} \mathrm{Fe}(\mathrm{NO})(26 \mathrm{mg}, 0.02 \mathrm{mmol})$ was added to a $20 \mathrm{~mL}$ vial with septum cap and stir bar. $10 \mathrm{~mL}$ tetrahydrofuran was added and the vial was quickly sealed. Upon dissolving, the solution appeared brown. After stirring for $24 \mathrm{hr}$, the headspace was analyzed via GCMS. A blue precipitate was observed in a brown-orange solution.

\section{Supplementary Material}

Refer to Web version on PubMed Central for supplementary material.

\section{Acknowledgments}

This research was supported by the NIH (R01-GM102687B) and the Dreyfus Teacher-Scholar Program (T.A.). C.J.R. thanks the Resnick Sustainability Institute at Caltech for a fellowship. We thank Mike Takase and Larry Henling for assistance with crystallography, and Jonas Peters for use of his laboratory's Mössbauer spectrometer. C.J.R. is grateful to Graham de Ruiter and Niklas Thompson for insightful discussions.

\section{References}

1. Bertini I, Gray HB, Stiefel EI, Valentine JS. Biological Inorganic Chemistry: Structure and Reactivity. 1. University Science Books; Sausolito, California: 2007.

2. (a) Peters JW, Stowell MHB, Soltis SM, Finnegan MG, Johnson MK, Rees DC. Redox-Dependent Structural Changes in the Nitrogenase P-Cluster. Biochemistry. 1997; 36(6):1181-1187. [PubMed: 9063865] (b) Liu J, Chakraborty S, Hosseinzadeh P, Yu Y, Tian S, Petrik I, Bhagi A, Lu Y. Metalloproteins Containing Cytochrome, Iron-Sulfur, or Copper Redox Centers. Chem Rev. 2014; 114(8):4366-4469. [PubMed: 24758379] (c) Brown K, Djinovic-Carugo K, Haltia T, Cabrito I, Saraste M, Moura JG, Moura I, Tegoni M, Cambillau C. Revisiting the Catalytic $\mathrm{Cu}_{Z}$ Cluster of Nitrous Oxide $\left(\mathrm{N}_{2} \mathrm{O}\right)$ Reductase: Evidence of a Bridging Inorganic Sulfur. J Biol Chem. 2000; 275(52):41133-41136. [PubMed: 11024061] (d) Drennan CL, Heo J, Sintchak MD, Schreiter E, Ludden PW. Life on carbon monoxide: X-ray structure of Rhodospirillum rubrum Ni-Fe-S carbon monoxide dehydrogenase. Proc Natl Acad Sci. 2001; 98(21):11973-11978. [PubMed: 11593006] (e) Dobbek H, Svetlitchnyi V, Gremer L, Huber R, Meyer O. Crystal Structure of a Carbon Monoxide Dehydrogenase Reveals a [Ni-4Fe-5S] Cluster. Science. 2001; 293(5533):1281-1285. [PubMed: 11509720]

3. (a) Ferreira KN, Iverson TM, Maghlaoui K, Barber J, Iwata S. Architecture of the Photosynthetic Oxygen-Evolving Center. Science. 2004; 303(5665):1831-1838. [PubMed: 14764885] (b) Umena Y, Kawakami K, Shen JR, Kamiya N. Crystal Structure of Oxygen-Evolving Photosystem II at a Resolution of $1.9 \AA$ A. Nature. 2011; 473(7345):55-60. [PubMed: 21499260]

4. (a) Einsle O, Tezcan FA, Andrade SLA, Schmid B, Yoshida M, Howard JB, Rees DC. Nitrogenase MoFe-Protein at $1.16 \AA$ Resolution: A Central Ligand in the FeMo-Cofactor. Science. 2002; 297(5587):1696-1700. [PubMed: 12215645] (b) Lancaster KM, Roemelt M, Ettenhuber P, Hu Y, Ribbe MW, Neese F, Bergmann U, DeBeer S. X-ray Emission Spectroscopy Evidences a Central Carbon in the Nitrogenase Iron-Molybdenum Cofactor. Science. 2011; 334(6058):974-977. [PubMed: 22096198] (c) Spatzal T, Aksoyoglu M, Zhang L, Andrade SLA, Schleicher E, Weber S, Rees DC, Einsle O. Evidence for Interstitial Carbon in Nitrogenase FeMo Cofactor. Science. 2011; 334(6058):940. [PubMed: 22096190]

5. (a) Churchill MR, Wormald J. Crystal and molecular structure of tetramethylammonium carbidohexadecacarbonylhexaferrate (2-), $\left[\mathrm{Me}_{4} \mathrm{~N}_{2}\left[\mathrm{Fe}_{6}(\mathrm{CO})_{16} \mathrm{C}\right]\right.$, a hexanuclear iron cluster complex with an encapsulated six-co-ordinate carbon atom. J Chem Soc, Dalton Trans. 1974; (22): 2410-2415.(b) Churchill MR, Wormald J, Knight J, Mays MJ. Synthesis and crystallographic characterization of bis(tetramethylammonium) carbidohexadecacarbonylhexaferrate, a hexanuclear carbidocarbonyl derivative of iron. J Am Chem Soc. 1971; 93(12):3073-3074.(c) Kuppuswamy S, Wofford JD, Joseph C, Xie ZL, Ali AK, Lynch VM, Lindahl PA, Rose MJ. Structures, Interconversions, and Spectroscopy of Iron Carbonyl Clusters with an Interstitial Carbide: Localized 
Metal Center Reduction by Overall Cluster Oxidation. Inorg Chem. 2017; 56(10):5998-6012. [PubMed: 28441025] (d) Čorić I, Holland PL. Insight into the Iron-Molybdenum Cofactor of Nitrogenase from Synthetic Iron Complexes with Sulfur, Carbon, and Hydride Ligands. J Am Chem Soc. 2016; 138(23):7200-7211. [PubMed: 27171599]

6. Taheri A, Berben LA. Tailoring Electrocatalysts for Selective $\mathrm{CO}_{2}$ or $\mathrm{H}^{+}$Reduction: Iron Carbonyl Clusters as a Case Study. Inorg Chem. 2016; 55(2):378-385. [PubMed: 26689238]

7. (a) Ohki Y, Ikagawa Y, Tatsumi K. Synthesis of New [8Fe-7S] Clusters: A Topological Link between the Core Structures of P-Cluster, FeMoco, and FeFeco of Nitrogenases. J Am Chem Soc. 2007; 129(34):10457-10465. [PubMed: 17676736] (b) Ohta S, Ohki Y, Hashimoto T, Cramer RE, Tatsumi K. A Nitrogenase Cluster Model $\left[\mathrm{Fe}_{8} \mathrm{~S}_{6} \mathrm{O}\right]$ with an Oxygen Unsymmetrically Bridging Two Proto-Fe $\mathrm{S}_{3}$ Cubes: Relevancy to the Substrate Binding Mode of the FeMo Cofactor. Inorg Chem. 2012; 51(21):11217-11219. [PubMed: 23098055] (c) Chen X-D, Duncan JS, Verma AK, Lee SC. Selective Syntheses of Iron-Imide-Sulfide Cubanes, Including a Partial Representation of the FeS-X Environment in the FeMo Cofactor. J Am Chem Soc. 2010; 132(45):15884-15886. [PubMed: 20977213] (d) Chen XD, Zhang W, Duncan JS, Lee SC. Iron-Amide-Sulfide and Iron-ImideSulfide Clusters: Heteroligated Core Environments Relevant to the Nitrogenase FeMo Cofactor. Inorg Chem. 2012; 51(23):12891-12904. [PubMed: 23148670] (e) Powers TM, Betley TA. Testing the Polynuclear Hypothesis: Multielectron Reduction of Small Molecules by Triiron Reaction Sites. J Am Chem Soc. 2013; 135(33):12289-12296. [PubMed: 23865953] (f) Fout AR, Zhao Q, Xiao DJ, Betley TA. Oxidative Atom-Transfer to a Trimanganese Complex To Form $\mathrm{Mn}_{6}\left(\mu_{6}-\mathrm{E}\right)(\mathrm{E}=\mathrm{O}, \mathrm{N})$ Clusters Featuring Interstitial Oxide and Nitride Functionalities. J Am Chem Soc. 2011; 133(42): 16750-16753. [PubMed: 21942370] (g) Cinco RM, Rompel A, Visser H, Aromí G, Christou G, Sauer K, Klein MP, Yachandra VK. Comparison of the Manganese Cluster in Oxygen-Evolving Photosystem II with Distorted Cubane Manganese Compounds through X-ray Absorption Spectroscopy. Inorg Chem. 1999; 38(26):5988-5998. [PubMed: 11671305] (h) Bobrik MA, Laskowski EJ, Johnson RW, Gillum WO, Berg JM, Hodgson KO, Holm RH. Selenium substitution in $\left[\mathrm{Fe}_{4} \mathrm{~S}_{4}(\mathrm{SR})_{4}\right]^{2-}$ : synthesis and comparative properties of $\left[\mathrm{Fe}_{4} \mathrm{X}_{4}\left(\mathrm{YC}_{6} \mathrm{H}_{5}\right)_{4}\right]^{2-}(\mathrm{X}, \mathrm{Y}=$ sulfur, selenium) and the structure of $\left[\left(\mathrm{CH}_{3}\right)_{4} \mathrm{~N}_{2}\left[\mathrm{Fe}_{4} \mathrm{Se}_{4}\left(\mathrm{SC}_{6} \mathrm{H}_{5}\right)_{4}\right]\right.$. Inorg Chem. 1978; 17(6):1402-1410. (i) Di Francesco GN, Gaillard A, Ghiviriga I, Abboud KA, Murray LJ. Modeling Biological Copper Clusters: Synthesis of a Tricopper Complex, and Its Chloride- and Sulfide-Bridged Congeners. Inorg Chem. 2014; 53(9):4647-4654. [PubMed: 24745804]

8. (a) de Ruiter G, Thompson NB, Lionetti D, Agapie T. Nitric Oxide Activation by Distal Redox Modulation in Tetranuclear Iron Nitrosyl Complexes. J Am Chem Soc. 2015; 137(44):1409414106. [PubMed: 26390375] (b) de Ruiter G, Thompson NB, Takase MK, Agapie T. Intramolecular C-H and C-F Bond Oxygenation Mediated by a Putative Terminal Oxo Species in Tetranuclear Iron Complexes. J Am Chem Soc. 2016; 138(5):1486-1489. [PubMed: 26760217] (c) de Ruiter G, Carsch KM, Gul S, Chatterjee R, Thompson NB, Takase MK, Yano J, Agapie T. Accelerated Oxygen Atom Transfer and C-H Bond Oxygenation by Remote Redox Changes in $\mathrm{Fe}_{3} \mathrm{Mn}$ Iodosobenzene Adducts. Angew Chem Int Ed. 2017; 56(17):4772-4776.(d) Han Z, Horak KT, Lee HB, Agapie T. Tetranuclear Manganese Models of the OEC Displaying Hydrogen Bonding Interactions: Application to Electrocatalytic Water Oxidation to Hydrogen Peroxide. J Am Chem Soc. 2017; 139(27):9108-9111. [PubMed: 28587453]

9. Tsui EY, Kanady JS, Day MW, Agapie T. Trinuclear First Row Transition Metal Complexes of a Hexapyridyl, Trialkoxy 1,3,5-triarylbenzene Ligand. Chem Commun. 2011; 47(14):4189-4191.

10. McCleverty JA. Chemistry of Nitric Oxide Relevant to Biology. Chem Rev. 2004; 104(2):403-418. [PubMed: 14871130]

11. (a) Victor E, Lippard SJ. A Tetranitrosyl [4Fe-4S] Cluster Forms En Route to Roussin's Black Anion: Nitric Oxide Reactivity of $\left[\mathrm{Fe}_{4} \mathrm{~S}_{4}\left(\mathrm{LS}_{3}\right) \mathrm{L}^{\prime}\right]^{2-}$. Inorg Chem. 2014; 53(10):5311-5320. [PubMed: 24773390] (b) Tran CT, Williard PG, Kim E. Nitric Oxide Reactivity of [2Fe-2S] Clusters Leading to H2S Generation. J Am Chem Soc. 2014; 136(34):11874-11877. [PubMed: 25113815] (c) Harrop TC, Tonzetich ZJ, Reisner E, Lippard SJ. Reactions of Synthetic [2Fe-2S] and [4Fe-4S] Clusters with Nitric Oxide and Nitrosothiols. J Am Chem Soc. 2008; 130(46): 15602-15610. [PubMed: 18939795]

12. (a) Majumdar A, Lippard SJ. Non-Heme Mononitrosyldiiron Complexes: Importance of Iron Oxidation State in Controlling the Nature of the Nitrosylated Products. Inorg Chem. 2013; 52(23): 13292-13294. [PubMed: 24246021] (b) Awasabisah D, Xu N, Gautam KPS, Powell DR, Shaw 
MJ, Richter-Addo GB. Preparation, Characterization, Electrochemistry, and Infrared Spectroelectrochemistry of Ruthenium-Nitrosyl Porphyrins Containing 11-O-Bonded Axial Carboxylates. Eur J Inorg Chem. 2016; 2016(4):509-518.(c) Han B, Shao J, Ou Z, Phan TD, Shen J, Bear JL, Kadish KM. Synthesis and Characterization of Nitrosyl Diruthenium Complexes. Interaction between NO and CO across the Metal-Metal Bond. Inorg Chem. 2004; 43(24):7741-7751. [PubMed: 15554639] (d) Victor E, Minier MA, Lippard SJ. Synthesis and Characterization of a Linear Dinitrosyl-Triiron Complex. Eur J Inorg Chem. 2014; 2014(33):5640-5645.(e) Sidebotham RP, Beer PD, Hamor TA, Jones CJ, McCleverty JA. The synthesis, electrochemistry and molecular structure of $\left[\mathrm{Fe}\left(\eta_{5}-\mathrm{C}_{5} \mathrm{H}_{4} \mathrm{~S}\right) 2 \mathrm{Mo}(\mathrm{NO})\left\{\mathrm{HB}\left(3,5-\mathrm{Me}_{2} \mathrm{C}_{3} \mathrm{~N}_{2} \mathrm{H}\right)_{3}\right\}\right]$. J Organomet Chem. 1989; 371(2):C31-C34.

13. Herbert DE, Lionetti D, Rittle J, Agapie T. Heterometallic Triiron-Oxo/Hydroxo Clusters: Effect of Redox-Inactive Metals. J Am Chem Soc. 2013; 135(51):19075-19078. [PubMed: 24304416]

14. Enemark JH, Feltham RD. Principles of structure, bonding, and reactivity for metal nitrosyl complexes. Coord Chem Rev. 1974; 13(4):339-406.

15. Shannon R. Revised effective ionic radii and systematic studies of interatomic distances in halides and chalcogenides. Acta Crystallographica Section A. 1976; 32(5):751-767.

16. (a) Martirosyan GG, Kurtikyan TS, Azizyan AS, Iretskii AV, Ford PC. Weak coordination of neutral S- and O-donor proximal ligands to a ferrous porphyrin nitrosyl. Characterization of 6coordinate complexes at low T. J Inorg Biochem. 2013; 121:129-133. [PubMed: 23376554] (b) Praneeth VKK, Näther C, Peters G, Lehnert N. Spectroscopic Properties and Electronic Structure of Five- and Six-Coordinate Iron(II) Porphyrin NO Complexes: Effect of the Axial N-Donor Ligand. Inorg Chem. 2006; 45(7):2795-2811. [PubMed: 16562937] (c) Wyllie GRA, Schulz CE, Scheidt WR. Five- to Six-Coordination in (Nitrosyl)iron(II) Porphyrinates: Effects of Binding the Sixth Ligand. Inorg Chem. 2003; 42(18):5722-5734. [PubMed: 12950223] (d) Sharma SK, Kim H, Rogler PJ, Siegler AM, Karlin KD. Isocyanide or nitrosyl complexation to hemes with varying tethered axial base ligand donors: synthesis and characterization. JBIC Journal of Biological Inorganic Chemistry. 2016; 21(5):729-743. [PubMed: 27350154]

17. (a) Creutz SE, Peters JC. Catalytic Reduction of $\mathrm{N}_{2}$ to $\mathrm{NH}_{3}$ by an $\mathrm{Fe}-\mathrm{N}_{2}$ Complex Featuring a CAtom Anchor. J Am Chem Soc. 2014; 136(3):1105-1115. [PubMed: 24350667] (b) Rittle J, Peters JC. $\mathrm{Fe}-\mathrm{N}_{2} / \mathrm{CO}$ complexes that model a possible role for the interstitial $\mathrm{C}$ atom of FeMocofactor (FeMoco). Proc Natl Acad Sci. 2013; 110(40):15898-15903. [PubMed: 24043796] (c) Cammarota RC, Clouston LJ, Lu CC. Leveraging molecular metal-support interactions for H2 and N2 activation. Coord Chem Rev. 2017; 334:100-111.

18. (a) Speelman AL, Lehnert N. Characterization of a High-Spin Non-Heme $\{\mathrm{FeNO}\}^{8}$ Complex: Implications for the Reactivity of Iron Nitroxyl Species in Biology. Angew Chem Int Ed. 2013; 52(47):12283-12287.(b) Speelman AL, Zhang B, Krebs C, Lehnert N. Structural and Spectroscopic Characterization of a High-Spin $\{\mathrm{FeNO}\}^{6}$ Complex with an Iron(IV)-NOElectronic Structure. Angew Chem Int Ed. 2016; 55(23):6685-6688.

19. (a) Sanders BC, Patra AK, Harrop TC. Synthesis, properties, and reactivity of a series of non-heme $\{\text { FeNO }\}^{7 / 8}$ complexes: Implications for Fe-nitroxyl coordination. J Inorg Biochem. 2013; 118:115-127. [PubMed: 23116685] (b) Kupper C, Rees JA, Dechert S, DeBeer S, Meyer F. Complete Series of $\{\mathrm{FeNO}\}^{8},\{\mathrm{FeNO}\}^{7}$, and $\{\mathrm{FeNO}\}^{6}$ Complexes Stabilized by a Tetracarbene Macrocycle. J Am Chem Soc. 2016; 138(25):7888-7898. [PubMed: 27191681]

20. Taheri A, Thompson EJ, Fettinger JC, Berben LA. An Iron Electrocatalyst for Selective Reduction of $\mathrm{CO}_{2}$ to Formate in Water: Including Thermochemical Insights. ACS Catalysis. 2015; 5(12): 7140-7151.

21. Rauchfuss TB. Inorg Synth. John Wiley \& Sons, Inc; 2010. Bio-Inspired Iron and Nickel Complexes; 129-147.

22. Izod K, Rayner DG, El-Hamruni SM, Harrington RW, Baisch U. Stabilization of a Diphosphagermylene through $\mathrm{p} \pi-\mathrm{p} \pi$ Interactions with a Trigonal-Planar Phosphorus Center. Angew Chem Int Ed. 2014; 53(14):3636-3640.

23. (a) Larina NA, Lokshin V, Berthet J, Delbaere S, Vermeersch G, Khodorkovsky V. Synthesis and photochromism of a series of new 2-unsubstituted 3-2-benzylbenzoylquinolin-41H-ones. Tetrahedron. 2010; 66(42):8291-8299.(b) Kiss L, David L, Da Costa Pereira Rosa CP, De Nornha 
RG, Palma PNL, Da Silva AS, Beliaev A. Parmaceutical Compounds. US Patent. 2012/65191. Mar 15, 2012

24. Sun H, DiMagno SG. Anhydrous Tetrabutylammonium Fluoride. J Am Chem Soc. 2005; 127(7): 2050-2051. [PubMed: 15713075]

25. Yueh W, Bauld NL. Mechanistic Criteria for Cation Radical Reactions: Aminium Salt-Catalyzed Cyclopropanation. J Am Chem Soc. 1995; 117(21):5671-5676.

26. Barton DHR, Haynes RK, Leclerc G, Magnus PD, Menzies ID. New reactions of triplet oxygen which avoid the spin barrier. J Chem Soc, Perkin Trans 1. 1975; (20):2055-2065.

Inorg Chem. Author manuscript; available in PMC 2018 December 03. 

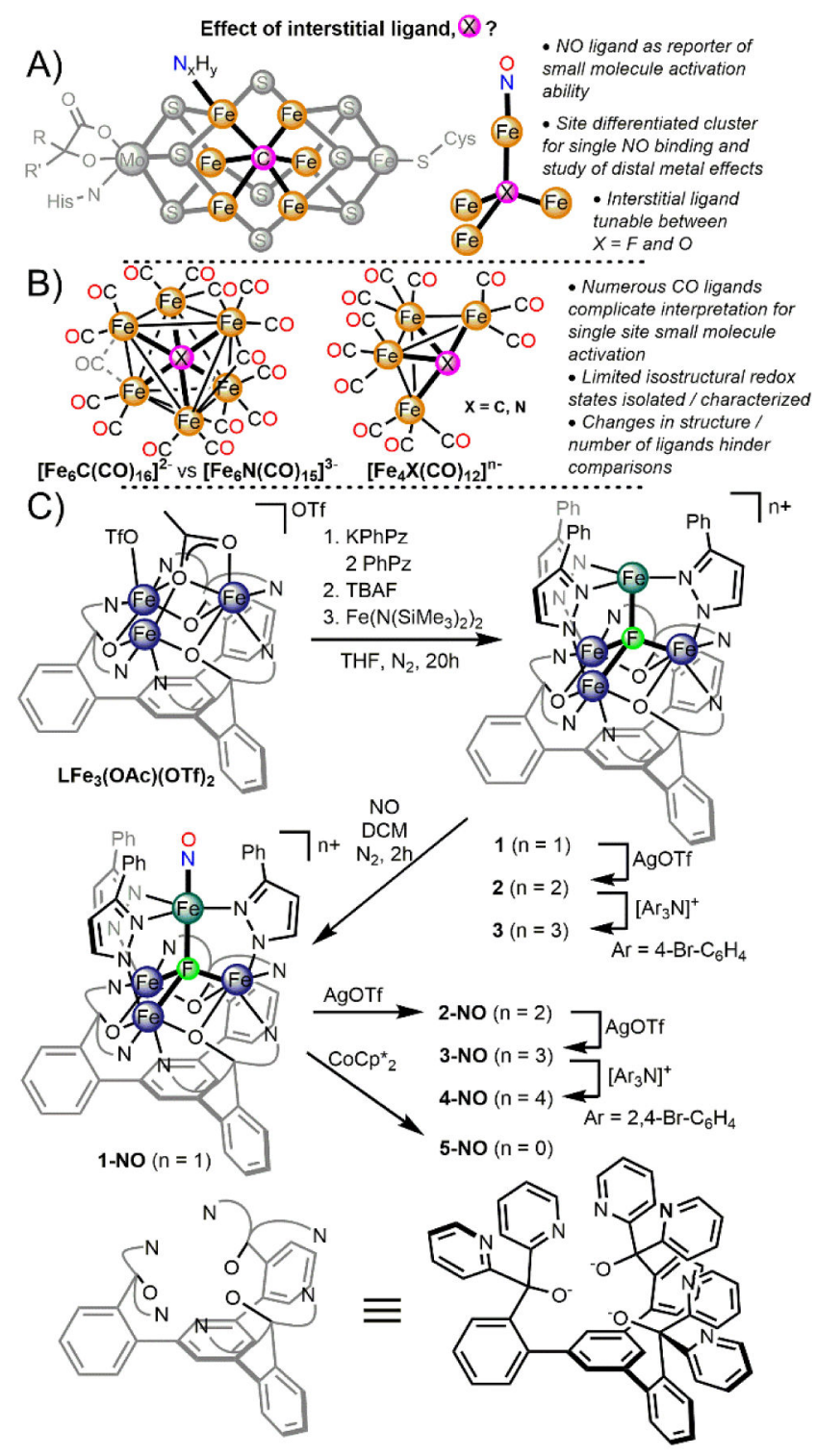

Figure 1.

(A) Left: Depiction of FeMoco cluster of nitrogenase with putative binding of nitrogenous ligand and design elements of the clusters reported herein (B) Reported Fe clusters with different interstitial (or psedo-interstitial, $\mathrm{X}$ ) and diatomic (CO) ligands; right, limitations of these clusters for determining the effect of interstitial ligand on small molecule activation (C) Synthesis of tetranuclear iron clusters. 


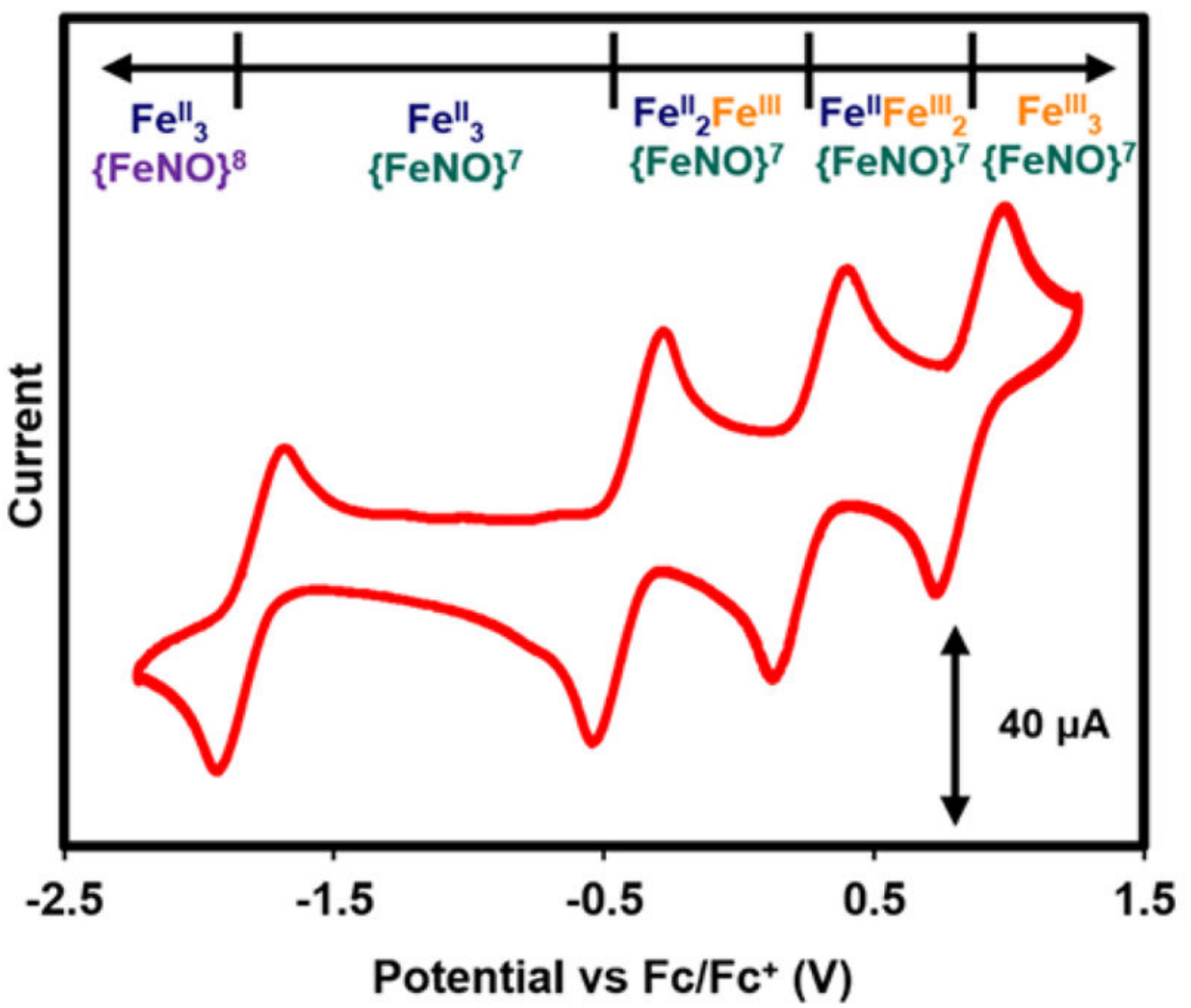

Figure 2.

Cyclic voltammogram of monocationic nitrosyl cluster, 1-NO $(2 \mathrm{mM})$ in $\mathrm{CH}_{2} \mathrm{Cl}_{2}$ with 100 $\mathrm{mM}\left[\mathrm{Bu}_{4} \mathrm{~N}\right]\left[\mathrm{PF}_{6}\right]$ at a scan rate of $200 \mathrm{mV} / \mathrm{s}$ with glassy carbon, Pt-wire, and Ag-wire as working, reference and counter electrode, respectively. The measured open-circuit potential (OCP) was $-0.7 \mathrm{~V}$. 

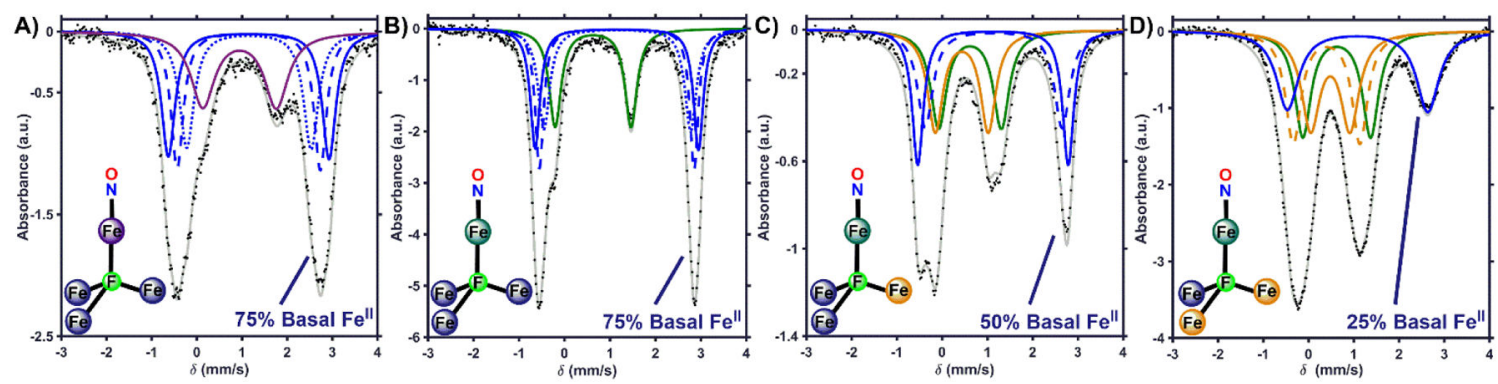

Figure 3.

Zero applied field ${ }^{57} \mathrm{Fe}$ Mossbauer spectra at $80 \mathrm{~K}$ of (A) 5-NO,(B) 1-NO, (C) 2-NO, (D) 3-

NO. Black dots represent the data, gray traces are the sum of the simulated fits, and colored traces represent the individual fits for the Fe centers (See Table 1 and SI for parameters). Blue traces represent assignments made to basal $\mathrm{Fe}^{\mathrm{II}}$, orange traces represent basal $\mathrm{Fe}^{\mathrm{III}}$ assignments, green and purple traces represent $\{\mathrm{FeNO}\}^{7}$ and $\{\mathrm{FeNO}\}^{8}$ units, respectively. 
A)

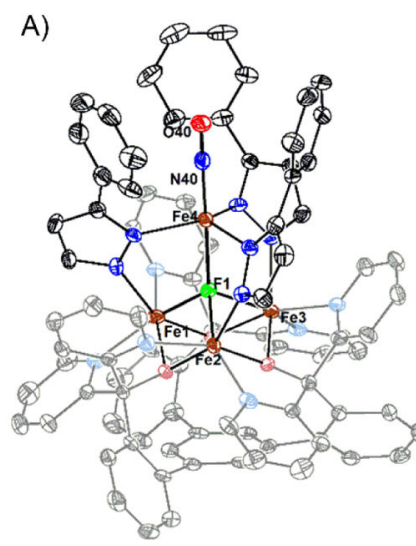

B)

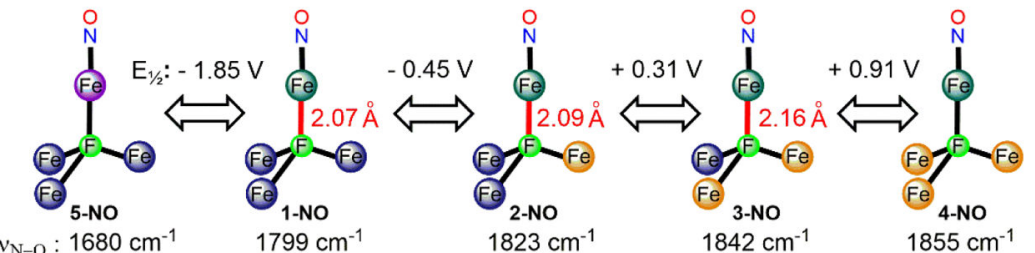

1

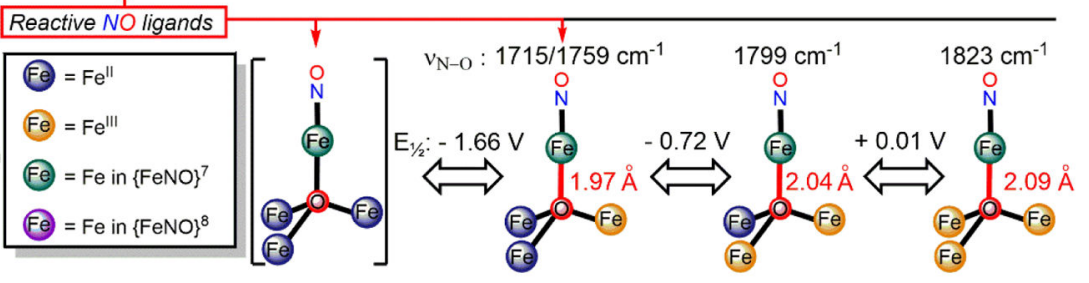

Figure 4.

(A) Crystal structure of tetranuclear iron nitrosyl cluster 2-NO with ellipsoids shown at the $50 \%$ probability level. Solvents molecules, outer-sphere counterions, and hydrogen atoms omitted for clarity. (B) Simplified depiction of the tetranuclear iron clusters discussed. Measured redox potentials, NO stretching frequencies, and apical $\mathrm{Fe}-\mu_{4}$-ligand distances are included for comparison. Data for the $\mu_{4} \mathrm{O}$ clusters were previously reported. ${ }^{8 \mathrm{a}}$ The $\left(\mu_{4}\right.$ O) $\mathrm{Fe}^{\mathrm{II}}{ }_{3}\{\mathrm{FeNO}\}^{7}$ state was observed electrochemically, but chemical reduction resulted in loss of the NO moiety, therefore $\nu_{\mathrm{N}-\mathrm{O}}$ was not determined. 


\section{Table 1}

$\mathrm{Fe}-\mu_{4} \mathrm{~F}$ Distances and Mössbauer Parameters for Complexes 1-NO - 5-NO with Oxidation State Assignments

\begin{tabular}{|c|c|c|c|c|}
\hline \multicolumn{5}{|c|}{ Complex } \\
\hline Fe Center & $\mathrm{Fe}-\mu_{4}-\mathrm{F}$ distance & $\delta$ & $\left|\Delta \mathbf{E}_{\mathbf{q}}\right|$ & Assign. \\
\hline \multicolumn{5}{|c|}{ 1-NO } \\
\hline $\mathrm{Fe} 1, \mathrm{Fe} 2, \mathrm{Fe} 3$ & $2.129(7) ; 2.205(6) ; 2.169(5) \AA$ & $1.15 ; 1.15 ; 1.16 \mathrm{~mm} / \mathrm{s}$ & $3.59 ; 3.40 ; 3.23 \mathrm{~mm} / \mathrm{s}$ & h.s. $\mathrm{Fe}^{\mathrm{II}}$ \\
\hline $\mathrm{Fe} 4$ & $2.065(7) \AA$ & $0.63 \mathrm{~mm} / \mathrm{s}$ & $1.67 \mathrm{~mm} / \mathrm{s}$ & $\{\mathrm{FeNO}\}^{7}$ \\
\hline \multicolumn{5}{|c|}{ 2-NO } \\
\hline $\mathrm{Fe} 1$ & $2.030(4) \AA$ & $0.44 \mathrm{~mm} / \mathrm{s}$ & $1.17 \mathrm{~mm} / \mathrm{s}$ & h.s. $\mathrm{Fe}^{\mathrm{III}}$ \\
\hline $\mathrm{Fe} 2, \mathrm{Fe} 3$ & $2.237(4) ; 2.101(4) \AA$ & $1.12 ; 1.15 \mathrm{~mm} / \mathrm{s}$ & $3.31 ; 3.03 \mathrm{~mm} / \mathrm{s}$ & h.s. $\mathrm{Fe}^{\mathrm{II}}$ \\
\hline $\mathrm{Fe} 4$ & 2.093(4) $\AA$ & $0.62 \mathrm{~mm} / \mathrm{s}$ & $1.39 \mathrm{~mm} / \mathrm{s}$ & $\{\mathrm{FeNO}\}^{7}$ \\
\hline \multicolumn{5}{|c|}{ 3-NO } \\
\hline $\mathrm{Fe} 1$ & 2.207(3) $\AA$ & $1.09 \mathrm{~mm} / \mathrm{s}$ & $3.10 \mathrm{~mm} / \mathrm{s}$ & h.s. $\mathrm{Fe}^{\mathrm{II}}$ \\
\hline $\mathrm{Fe} 2, \mathrm{Fe} 3$ & 2.080(3); 2.091(3) & $0.48 ; 0.40 \mathrm{~mm} / \mathrm{s}$ & $0.87 ; 1.47 \mathrm{~mm} / \mathrm{s}$ & h.s. $\mathrm{Fe}^{\mathrm{III}}$ \\
\hline $\mathrm{Fe} 4$ & $2.155(3) \AA$ & $0.62 \mathrm{~mm} / \mathrm{s}$ & $1.51 \mathrm{~mm} / \mathrm{s}$ & $\{\mathrm{FeNO}\}^{7}$ \\
\hline \multicolumn{5}{|c|}{ 4-NO ${ }^{a}$} \\
\hline $\mathrm{Fe} 1-\mathrm{Fe} 4$ & - & $0.47 \mathrm{~mm} / \mathrm{s}$ & $1.42 \mathrm{~mm} / \mathrm{s}$ & h.s. $\mathrm{Fe}^{\mathrm{III}}$ and $\{\mathrm{FeNO}\}^{7}$ \\
\hline \multicolumn{5}{|c|}{ 5-NO } \\
\hline $\mathrm{Fe} 1, \mathrm{Fe} 2, \mathrm{Fe} 3$ & - & $1.15 ; 1.15 ; 1.15 \mathrm{~mm} / \mathrm{s}$ & $3.56 ; 3.17 ; 3.75 \mathrm{~mm} / \mathrm{s}$ & h.s. $\mathrm{Fe}^{\mathrm{II}}$ \\
\hline $\mathrm{Fe} 4$ & - & $0.95 \mathrm{~mm} / \mathrm{s}$ & $1.63 \mathrm{~mm} / \mathrm{s}$ & $\{\mathrm{FeNO}\}^{8}$ \\
\hline
\end{tabular}

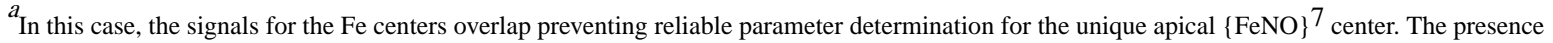
of an $\{\mathrm{FeNO}\}^{7}$ moiety is supported via the IR spectroscopy data. 